\title{
A Brief Contrast Between "Unfreeze Literature” in the Former Soviet Union and "Baihua Literature” in China
}

\author{
SUN Ying, ZHU Ping \\ Nanhu College of Jiaxing University, Jiaxing, China
}

\begin{abstract}
The theme of the Soviet Unfreeze Literature is to reveal the contradictions and the dark side of the society. It opposes bureaucracy, requires care and respect for people, fully affirms the value of people, shows the beauty of people, especially ordinary little people, and covers the humanitarian issues under the Proletarian Dictatorship. However, due to the different political environment and Chinese writers' own deficiencies in their comprehension of literature, there exists quite a huge gap between the works of "Baihua Literature" and those of "Unfreeze Literature" both in terms of the main subjects and in the form of artistic expression, although they appear in the same period of time. Thus, Chinese Baihua Literature is unable to take on the breakthrough mission of “Seventeen-Year Literature”, from which a hard lesson could be drawn to benefit the later literature policy.
\end{abstract}

Keywords: Unfreeze Literature, policy of literature, Chinese Baihua Literature

\section{Introduction}

As early as 1936, the new constitution was promulgated, announcing that the former Soviet society had eliminated class, established socialism, and demonstrated the complete match of productivity and production relations under the socialist system. So there was no more antagonistic contradictions in the society, instead there was only the difference between the advanced and the more advanced. This theory directly resulted in the birth of literary works that advocated "no conflict theory" and "whitewashing life". Later, the Soviet Communist Party's violent literary policy intervention during the post-war period brought the theory into full play. The novel Unfreeze became very influential after its appearance in 1954. Writers and critics carried out in-depth discussions around the content of the novel, about whether literature and art should reflect the "dark side" of life, writers' attitude in writing, and how to reflect the real problems, etc.. This not only made the literary circle have consistent understanding of the practical problems in writing, but also made the open and free atmosphere become more common in the literary circle. After Stalin's (1879-1953) death, the political climate of the former Soviet Union became loose and the literary atmosphere experienced an unprecedented heat and liveliness. Many writers put their long-brewing ideas on paper. They shared similar characteristics in their writing, that is, taking active and bold intervention in life, exposing the conflicts, and criticizing bureaucracy and backwardness in leadership. Their creation "unfroze" the literary works of rural subjects, 
signifying that the short story in the former Soviet Union entered a period of blossom.

\section{The Background and Development of the "Unfreeze Literature"}

In the 1950s, China's policy of literature and art was deeply influenced by that of the former Soviet Union. During this period of time, "Unfreeze Literature" of former Soviet Union and the Chinese "Baihua Literature" became the historical product of the times, with the former a product of "no conflict theory" and "whitewashing life". The post-war former Soviet Union was facing the tough task of rebuilding the country, and people were leading an underprivileged life in spite of the victory of war, which brought serious casualties of labor force as well as the shortage of materials. Unsteady factors were lurking around as a result of the pressure of survival and the trauma of war. Worse still, the "cold war" policy enforced by Western countries during this period of time had intensified the Soviet government's worries about the unsteadiness. Hence, the authorities of the former Soviet Union needed to mobilize the people to return to work after the war, and to protect the reconstruction work against the negative influence of the West. The violent behavior of Zhdanovism after the war in the field of literature was an attempt by the Soviet communist Party to solve the problem. This left-leaning behavior seemed to have suppressed the creation of more literary works, but problems in real life became more acute under the pressure, and the voice for freedom from those at the very bottom grew stronger and stronger.

Stalin revised his wording in the report of Socialist Economic Problems (1952) about the consistency of productivity and production relations under socialist system, admitting that there still existed contradictions in socialist society in 1952. And the central government of the Soviet Communist Party as well as the theoretical circle began to re-examine the nature of the social contradictions in former Soviet Union, admitting the existence of negative phenomena. The publishing of the report played a key role in fixing the underlying mess, enabling the people of the former Soviet Union to clearly see the contradictions and problems in real life.

Literary and art workers began to reflect on this and have discussions, and quickly they exemplified their ideas in their works. After Stalin's death in March 1953, Khrushchev (1894-1971) became the new leader of the former Soviet Union, greatly transforming the political life. People of the former Soviet Union started to feel the substantial benefits brought by the change of political climate. Since then on, the positive achievements of discussions against "conflict-free theory" and whitewashing life had inspired writers, the air of liberation gradually was formed in the literary circle. Finally, the spring of literature that people had been yearning for a long time had arrived.

"Unfreeze Literature" was the product of slogans such as "literature should positively intervene in life", "writing about true life", anti-formalism, anti-idea-free, anti-whitewashing reality and so on. After Khrushchev came to power, "Unfreeze Literature" revealed the contradiction of social life and the dark side of the society. For instance, it opposed to bureaucracy, requested care and respect for people, fully affirmed people's value, showed the beauty of people, especially ordinary little people, and it also covered humanitarian problems under the dictatorship of the proletariats. The novel of Unfreeze by Ilya Grigoryevich Ehrenburg (1891-1967) published in 1954 became the first representative work after the anti-conflict-free campaign came into full swing. It represented the essence and trend of "Unfreeze Literature", namely, literature ought to intervene in the real life and describe the real life.

"Unfreeze Literature" was a new period of development in the literature of the former Soviet Union. The 
theoretical development and creative practice of this period was mutually promoted, which allowed "Unfreeze Literature" to carry on more deeply for the next decade, and what is more importantly, exerted a profound influence on contemporary Soviet literature. Unfortunately, Stalin's regime failed to grasp this opportunity. Instead, it contained, controlled, and even condemned and suppressed it. Fortunately, thanks to the persistence of former Soviet writers, the hard "unfreeze" reached the climax of a literary Renaissance.

Held in December 1954 after Stalin's death, the second Writer Congress of the Soviet Union sharply criticized the literary works in Stalin's era for their formulation, generalization, and whitewashing ills, requiring the writers to reveal true life, to explain the contradictions and struggles in life, and to oppose formalism and lack of ideas.

Simonov (1915-1979) stressed several times in his conference report the importance of depicting real life truly and writers' sincere attitude in writing:

Therefore, I would like to point out that any distortion to real life would not only lead to error in aesthetics, but eventually cause various shortcomings and errors of ideas, whether it is the keenness on the dark side of life, the indifference of development and progress in life, or the beautification of life. (as cited in LIN, 1999, p. 33)

"Socialist ideas cannot be based on lies. Only the true life can become the real foundation of literary creation, rather than something imaginary" (as cited in LIN, 1999, p. 33). His address at such an important meeting was accepted by the participants, and it accelerated the development of "Unfreeze Literature".

After Stalin's death, the political climate of the former Soviet Union became loose and the literary atmosphere experienced an unprecedented heat and liveliness. Many writers put their long-brewing ideas on paper. After the 20th Congress in February 1956, "Unfreeze Literature” experienced new development by criticizing "personal worship". At the 30th Conference of the Communist Party of the former Soviet Union, Khrushchev made a secret report entitled Personal Worship and its Consequences (1961), causing an uproar at home and abroad. Not only did this become one of the most significant historical events in the world after the World War II, but it had a profound impact on many aspects of social life in the former Soviet Union. In the report, Khrushchev listed Stalin's historical wrongdoings committed during his term, as well as his cruelty during the "Purge". He requested that the party condemn and eradicate personal worship, completely eliminating its serious consequences. This was a scathing critique of the intensive dominance model of Stalin, and it also became the turning point of the social life in the former Soviet Union. The ideological trend of "unfreeze Literature” began to involve anti-personal superstition and exposition of the mistakes of the former policy, etc.. Related articles emerged constantly in literary journals. For instance, the editorial on Literary Newspaper in August 1956 pointed out that "... The kind of personal worship, which is contradictory to Marxism, and its due consequences have brought giant losses to our cause.” "Personal worship does bring great harm to our literature.” "Bizarre phenomena that appeared in the literature, such as no conflict theory, whitewashing reality, carefree and idyllic description of the reality, are all related to personal worship” (as cited in LIN, 1999, p. 50). After the 20th Congress, the rehabilitation of writers continued, and a large number of young writers emerged, their clear consciousness and mind contributing a lot to the campaign of "Unfreeze Literature". The literary creation during this period were improved in quality and quantity, enriching the cultural life of the people, and sending the literature into a more prosperous development stage. 


\section{The Impact of “Unfreeze Literature” on "Baihua Literature”}

In 1952, the ninth issue of Wenyi Bao (Literary Gazette) re-published two articles: “Overcoming the Backwardness of Literature and Art” on the April 7 issue of Pravda, and "Failing the People” on the April 8 issue of Literary Newspaper, taking the lead in bringing into China the literary thoughts of "anti-conflict-free theory" and whitewashing life. At the end of 1954, the second Writers' Congress of the former Soviet Union became an important symbol of all-round development of "Unfreeze literature". Chinese writers also attached great importance to this event, republishing the meeting report with the fastest speed on important journals in China. Hence, China also began to review the errors in her work. MAO Ze-dong also realized that criticism must be carried out on the problems arising from the work. On the National Congress of the Communist Party of China held in March 1955, he pointed out that "given the shortcomings and mistakes in our work, a public criticism and self-criticism must be carried out” (as cited in ZHANG, 1957, p. 105). On April 5, 1956, People’s Daily published an editorial entitled "Historical Experience of the Proletariat Dictatorship", which pointed out that there still existed bureaucracy and dogmatism in our country. As for bureaucracy, the editorial said:

Due to the various forms of bureaucracy, the leaders and staffs of our party and our country are apt to abuse their power, isolate themselves from the masses as well as the collective leadership, practice authoritarianism, and destroy the party and the country's democracy, which is a very dangerous situation.” (as cited in ZHANG, 1957, p. 105)

At the enlarged meeting of the political bureau of the Central Committee and the 17th meeting of supreme state conference on April 28, 1956, MAO said: “The principle of letting a hundred flowers blossom and a hundred schools of thought contend should be our policy. Let the flowers of art blossom, and schools of academic thought contend” (as cited in Fromm, 1987, p. 353). On March 12, 1957, he further put forward that the principle should apply to all walks of life. He said, "The principle is not only a good way of developing science and art, if promoted to more fields, it is also a good method of doing all the work. This method can help us reduce our mistakes” (as cited in ZHAO, 1980, p. 415).

Under the inspiration of "Unfreeze Literature" of the former Soviet Union and the principle of "letting a hundred flowers blossom and a hundred schools of thought contend”, some Chinese writers started to learn from the "Unfreeze” writers of the former Soviet Union, attacking bureaucracy and dogmatism head-on. In China, QIN Zhao-yang (1916-1994), editor of People’s Literature and HUANG Qiu-yun (1918-2001), editor of Literary Study were also doing the same thing. QIN Zhao-yang selected and published a series of novels that contained fierce criticism of bureaucracy and dogmatism. These novels bore great similarities with the "Unfreeze Literature” stories of the former Soviet Union. They described a group of idealistic, talented young people with communist ideal, who fought with indifferent, inefficient, and timid bureaucrats. QIN Zhao-yang had a group of good writers working for him, such as LIU Bin-yan (1925-2005), WANG Meng (1934- ), LIU Shao-tang (1936-1997), who deemed it their duty to criticize bureaucracy and dogmatism. In 1956, the famous anti-bureaucracy novel On the Working Site of a Bridge by LIU Bin-yan was carried on the 4th issue of People's Literature. In the editor's note QIN Zhao-yang wrote: “We’ve been expecting such critical and ironic features in writing for a long time” (as cited in LIU, 1985, p. 34).

LIU Bin-yan's two novels On the Working Site of a Bridge (1956) and Inside Information of Our Paper (1956) uncovered the prelude of "Baihua Literature”. The topics of the literary works during this period of time 
were very common in daily life after the founding of the People's Republic of China, but no writers so far dared to write about them. So the phenomenon caused quite a sensation among the readers, who were so excited to read about the truth. After that, an abundant literary works directed at bureaucracy and dogmatism sprang up one after another, among which the most distinguished one was WANG Meng's novel called The Young Newcomer of the Organization Department, published on the 9th issue of People's Literature in 1956. At the same time, the field of literary criticism also had a strong outcry against bureaucracy and dogmatism.

\section{The Innate Deficiency of “Baihua Literature” and Its Final “Destination”}

Unfortunately, the "unfreeze" trend of the Communist literature policy failed to hold out. To reduce the worries of Soviet Communist Party leaders and to be more beneficial to the development of "Unfreeze Literature”, "unfreeze” writers assured the Central Government of the Soviet Communist Party at the second Congress of Russian Federation Writers held from March 3 to 7, 1965, that they were able to oppose to Stalinism more violently on the premise that they were not against Leninism. The field of Chinese art and literature, on the contrary, was not that fortunate. The incidents happened in Poland and Hungary in the second half of 1956 and the student unrest like Shijiazhuang of Hebei, Hanyang of Hubei at the end of 1956 and the first half of 1957 greatly changed MAO's attitude toward "Baihua Literature", which further changed his literary thought later on. Also, international and domestic tensions added to the nervousness of MAO, who had always been in war state. After the enforcement of "Double hundred policy", he argued, not only did "fragrant flowers" appear, but also the "poisonous weeds" among the literary works. The fierce criticisms made by "Baihua Literature” toward bureaucracy and dogmatism led to MAO's conviction that they were not conducive to the socialist construction, or to consolidation of the leadership of the Communist Party, thus they became the "poisonous weeds" that must be got rid of.

Besides the sudden change of political winds, the innate deficiency of "Baihua Literature" itself explained why it would not go any further. The writers at that time were often too straightforward to express their view of a certain social problem, and too eager to take literature as a weapon to promote social process. As a result, their works tended to restrict themselves to the interpretation of such social problems as bureaucracy, and failed to observe more carefully people's variation and dehumanization under the erosion of bureaucratic ideas. Their novel explored bureaucratic obstruction of national construction and the damage on people's material interests from a political perspective, but seldom covered the harm of bureaucracy on the people themselves. As an important part of the humanitarian, concepts like "human nature" and "humanity" were narrowly understood and classified as simple emotion. They were completely stripped away from the politics, and were even criticized as a key reflection of bourgeois emotion. Humanitarian ideas were simplified as sovereignty consciousness and the proletarian class emotion, whereas the other rich connotations in it were suspended. Therefore, without fully understanding the humanitarian ideas, the Chinese writers were mostly limited to the criticism of political thought when they were revealing the dark side of the society, which also affected the development of literary theme. With the fleet of "hundred blossoms" era, writers of "Baihua Literature" failed to care for people's inner world, as they were too eager to reflect social contradictions. Compared with the works of "Unfreeze Literature", those of "Baihua Literature" had relatively monotonous aesthetic style. 


\section{Conclusions}

"Baihua Literature" strove to break through the original creation model of formulation and generalization, but since China's traditional humanistic ideas were much less profound than those of the former Soviet Union, Chinese writers failed to understand humanitarian ideas, for they were still restricted by the political context. On the other hand, the relative scarcity of mental resources of Chinese writers, and their total breakdown with Western culture destined that writers of "Baihua Literature" were still unable to shoulder the mission of pushing the "seventeen-year literature" out to the surface. Hence, there existed a huge gap between the works of "Baihua Literature" and those masterpieces of "Unfreeze Literature" both in terms of the theme and the artistic expression.

\section{References}

Fromm, F. (1987). Escape from freedom (p. 353). Harbin: Northern Arts Publishing House.

LIN, X. Z. (1999). Spirit of May Fourth Movement. The Study, (6), 33.

LIU, B. Y. (1985). On literature and life (p. 34). Beijing: People’s Literature Publishing House.

ZHANG, T. Y. (1957). Love on the cliff. Literary Study, (1), 105.

ZHAO, S. L. (1980). Before and after my writing experience at Three Mile Bay (p. 415). Beijing: Workers' Press. 